\title{
非円形細胞軟部肉腫に対する化学療法の安全性
}

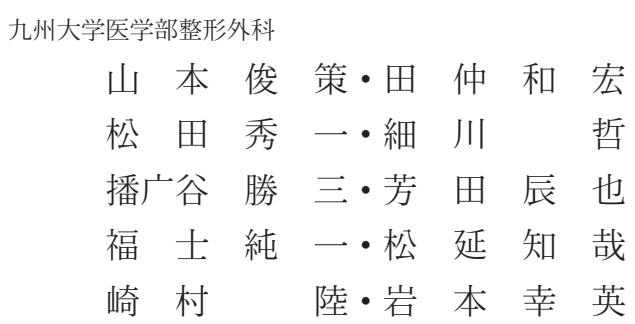

\section{Feasibility of Chemotherapy in Treatment of Adult Soft Tissue Sarcomas}

\author{
Shunsaku Yamamoto, Kazuhiro Tanaka, Shuichi Matsuda, \\ Akira Hosokawa, Katsumi Harimaya, Tatsuya Yoshida, \\ Jun-ichi Fukushi, Tomoya Matsunobu, \\ Riku Sakimura, and Yukihide Iwamoto \\ Depertment of Orthopedic surgery, Kyusyu University Faculty \\ of Medicine, Fukuoka, Japan
}

\begin{abstract}
We evaluated the toxicity and feasibility of chemotherapy for patients with soft tissue sarcomas. A total of 13 patients were treated in our department from 1998 to 2003. The median age of the patients was 42.6 years. The patients were treated with a combination of IFO+ADM+CDDP (11 courses), IFO+EPI (10 courses), or IFO+ADM (43 courses), or IFO (6 courses). Toxicities were assessed according to the National Cancer Institute-common toxicity criteria. Hematologic toxicities were anemia (29\% grade 3 and 4), leukopenia (99\%), neutoropenia (100\%) and thrombopenia (13\%). Nonhematologic toxicities were mainly nausea or vomiting (grade 1 and 2).

All courses were completed despite the occurrence of these toxicities.

Chemotherapy using high-dose IFO and ADM proved feasible with intense supportive treatment in adult soft tissue sarcomas.
\end{abstract}

Key words : adult soft tissue sarcoma (非円形細胞軟部肉腫), chemotherapy（化学療法), feasibility (安全性)

目的

高悪性度軟部肉腫のうち, 円形細胞軟部肉腫に対す る化学療法の有効性は確立しているが，非円形細胞軟 部肉腫に対する評価は定まっていない，今回われわれ は，標準的治療としての化学療法導入に先立ち，その 安全性について検討を加えた。

\section{対象と方法}

過去 5 年間に当科において化学療法を施行した非円 形細胞軟部肉腫患者 13 例（男性 7 例，女性 6 例）を 対象とした。平均年齢 42.6 歳 (15-65 歳), 組織型 は MFH 3 例, 平滑筋肉腫 2 例, 滑膜肉腫 3 例, 脂肪 肉腫 5 例であった。化学療法レジメンは合計 75 コー

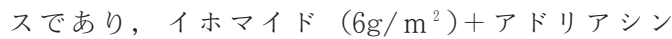
$\left(60 \mathrm{mg} / \mathrm{m}^{2}\right)+$ シスプラチン $\left(60 \mathrm{mg} / \mathrm{m}^{2}\right)$ (以下 IAP) 
の組み合わせが 11 コース，イホマイド $\left(7.5 \mathrm{~g} / \mathrm{m}^{2}\right)+$

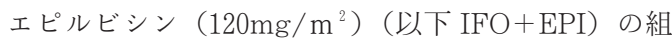

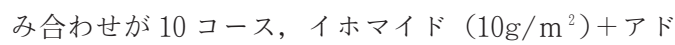

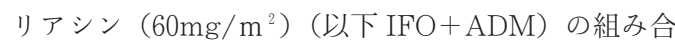
わせが 48 コース，イホマイド（10～ $16 \mathrm{~g} / \mathrm{m}^{2}$ ）（以下 IFO）単剤が 6 コースであった. 術前化学療法として 行われた症例が 5 例, 術後化学療法としてが 4 例, 再 発転移病巣に対してが 4 例であった。

\section{結果}

National Cancer Institute-common toxicity criteria（version2, 1999）を有害事象の評価基準とした. レジメン全体としての血液毒性は Grade3 以上の貧血 は全コースの $29 \%$, 白血球の減少は $98 \%$, 好中球の 減少は 100\%，血小板の減少は $13 \%$ に認められた。 ま た，非血液毒性として，Grade2 の悪心が 16\%，嘔吐 が $5 \%$ に認められた（表 1 )。さらに補充療法として 赤血球の輸血を 5 コースで実施した。その内訳は IAP で 3 コース, IFO+ADM で 2 コースであった. 血小板の輸血をIAP で 1 コースで実施した。2 週以 上の化学療法の遅延が認められたのは 7 コースであっ た。骨䯣抑制の遷延によるものは 3 コースあり, IAP, $\mathrm{IFO}+\mathrm{ADM}, \mathrm{IFO}$ にて，それぞれ 1 コースずつ認め られた。また, 感染症による遅延は 4 コースで全て $\mathrm{IFO}+\mathrm{EPI}$ の組み合わせによるものであった，この感 染症症例は同一症例であり, 左前腕部の蜂窩織炎に由 来するあのであった.

レジメン別の Grade3 以上の有害事象の発生頻度で は，いずれのレジメンにおいても好中球減少は必発で あった. IFO+ADM においては白血球の減少が 98\%, 貧血の頻度が 19\%であったが血小板減少は認められ なかった。 非血液毒性として, 同一症例ではあるが, 2 コース (4\%) で局所感染である肛門周囲膿瘍が認

表 1 : 全体の有害事象頻度

\begin{tabular}{lcccc}
\hline \hline & Grade1 & Grade2 & Grade3 & Grade 4 \\
\hline Hb. & $18(24 \%)$ & $35(46 \%)$ & $18(24 \%)$ & $4(5 \%)$ \\
WBC & 0 & $1(1 \%)$ & $20(26 \%)$ & $54(72 \%)$ \\
Neut. & 0 & 0 & $14(19 \%)$ & $61(81 \%)$ \\
PLT & $59(78 \%)$ & $7(9 \%)$ & $9(13 \%)$ & 0 \\
Nausea & $33(44 \%)$ & $12(16 \%)$ & 0 & 0 \\
Vomiting & $7(10 \%)$ & $3(5 \%)$ & 0 & 0 \\
\hline
\end{tabular}

められた。発熱性好中球減少は $10 \%$ に認められた。 IFO+EPI においては貧血の頻度が $50 \%$ ，血小板減 少が $20 \%$ に認められ，局所の蜂窩織炎に由来する感 染症の頻度が $50 \%$ と高く，プロトコール遅延の原因 となり，臨床上問題であった，IAPでは，貧血の頻 度が $73 \%$, 血小板減少の頻度が $64 \%$ と著明に高く, 発熱性好中球減少の頻度も $27 \%$ と高かった。 IFO 単 独では白血球数と好中球数の減少が必発であったが, 非血液毒性は認められなかった。レジメン全体で見る 之, 有害事象のため化学療法が不可能となる例はなかっ た（表 2 ).

\section{考察}

覀性軟部腫瘍に対する化学療法の代表的なレジメン として MAID がある. 米国 South Western Oncology Groupによる 170 例の報告において, IFO $\left(7.5 \mathrm{~g} / \mathrm{m}^{2}\right)+\operatorname{ADM}\left(60 \mathrm{mg} / \mathrm{m}^{2}\right)+\operatorname{DTIC}\left(1 \mathrm{~g} / \mathrm{m}^{2}\right)$ のレジメンでは Grade3 以上の血液毒性としては白血 球減少の頻度が $86 \%$, 貧血の頻度は $22 \%$, 血小板減 少の頻度が $26 \%$ であり，非血液毒性としては治療関 連死が $4 \%$, 悪心または嘔吐が 19\%, 粘膜障害が 9 \%, 中枢神経症状が $6 \%$ に認められた。このレジメン は, 奏効率も $32 \%$ と当初期待されたほどは高くなく, 治療関連死亡屯認められており, 有用性は低いと考え られている1)。 また， IFO $\left(9 \mathrm{~g} / \mathrm{m}^{2}\right)+$ epirubicin $\left(120 \mathrm{mg} / \mathrm{m}^{2}\right)$ の補助化学療法レジメンでは, Frustaci は Grade3 以上の血液毒性としては白血球減 少が 58\%，貧血が 20\%，血小板減少が 11\%と比較的 低く, Grade3 以上の非血液毒性としては，悪心また は嘔吐が $3 \%$ ，粘膜障害が 10\%に認められたと報告 している2). しかし，自験例では，他のレジメンと比 較しても血液毒性は強く, 半数で感染症を引き起こす など，日本人には安全性の面で難しいレジメンと考え

表 $2 ：$ レジメン別の有害事象頻度

\begin{tabular}{|c|c|c|c|c|c|}
\hline レジメン & WBC Neut. & $\mathrm{Hb}$. & PLT & 感染 & $\begin{array}{l}\text { 発熱性好 } \\
\text { 中球減少 }\end{array}$ \\
\hline $\mathrm{IFO}+\mathrm{ADM}$ & $98 \% \quad 100 \%$ & $19 \%$ & $0 \%$ & $4 \%$ & $10 \%$ \\
\hline $\mathrm{IFO}+\mathrm{EPI}$ & $100 \% 100 \%$ & $50 \%$ & $20 \%$ & $50 \%$ & $10 \%$ \\
\hline IAP & $100 \% 100 \%$ & $73 \%$ & $64 \%$ & $0 \%$ & $27 \%$ \\
\hline IFO & $100 \% 100 \%$ & $0 \%$ & $0 \%$ & $0 \%$ & $0 \%$ \\
\hline
\end{tabular}


られた。

一方，最近開発された G-CSF 併用により IFO， $\mathrm{ADM}$ を増量したレジメンでは, Patel らは IFO $\left(10 \mathrm{~g} / \mathrm{m}^{2}\right)+\operatorname{ADM}\left(90 \mathrm{mg} / \mathrm{m}^{2}\right)$ のレジメンに拈いて, Grade3 以上の白血球減少が 87\%，血小板減少が 55 \%に認められ, 非血液毒性としては主として発熱性好 中球減少症が $47 \%$ に認められたと報告している ${ }^{3)}$.

また，DepasらはIFO (12.5g/ m²) + ADM (60mg/ $\mathrm{m}^{2}$ ) のレジメンにおいて, 白血球減少が $59 \%$, 血小 板減少が $18 \%$, 貧血が $25 \%$ 認められ, 非血液毒性と しては発熱性好中球減少症が 16\%，粘膜障害が $7 \%$ に認められたが，いずれす実行可能であると述べてい る.また, 補助化学療法後の骨䯣抑制の頻度を減少さ せるために IFOを 10 日間にわけ，一日あたりの投与 量を減少させたレジメンにおいては Grade3-4 の好中 球減少は $30 \%$ にか認められなかったと報告してい $ろ^{4)}$.

さらに, $\mathrm{ADM}$ を $75 \mathrm{mg} / \mathrm{m}^{2}$ に固定し, IFO の dose を 8- $15 \mathrm{~g} / \mathrm{m}^{2} / 12$ days の 6 段階に増量して投与したレ ジメンでは, IFO $12 \mathrm{~g} / \mathrm{m}^{2} / 12$ days までであれば，奏 効率と有害事象の兼ね合いからみて現実的に有用であ ると報告しており，投与期間を延長しつつ，IFOの 投与総量を増量することで, 有害事象頻度を減少させ
つつ奏効率を上昇させることが可能であると結論づけ ている ${ }^{5)}$.

当科での $\operatorname{IFO}\left(10 \mathrm{~g} / \mathrm{m}^{2}\right)+\mathrm{ADM}\left(60 \mathrm{mg} / \mathrm{m}^{2}\right)$ の レジメンにおいては白血球減少が $98 \%$, 貧血が $19 \%$ に認められた。骨䯣抑制は高度であったものの，GCSF 併用下では 2 週以上のプロトコール遅延は $5 \%$ 未満であり，他のレジメンと比較しても安全に実行可 能と考えられた。（表 3 , 表 4 )

\section{結語}

非円形細胞軟部肉腫に対する IFO, ADM を中心と する化学療法は注意深い観察と支持療法を行うことで, 比較的安全に実施可能と考えられた。

\section{参 考 文 献}

1) Antman, K., et al. : An inter group phase III randomized study of doxorubicin and dacarbazine with or without ifosfamide and mesna in advanced soft tissue and bone sarcomas. Journal of clinical oncology, 11 (7) : 1276-1285, 1993.

2) De Pas, et al. : High-dose ifosfamide plus adriamycin in the treatment of adult advanced soft tissue sarcomas : is it feasible? Ann. Oncol., 9(8) : 807-809, 1998.

3) De Pas, et al. : Phase I study of twelve-day prolonged

表 3 : MAID, IFO+EPI の有害事象頻度

\begin{tabular}{|c|c|c|c|c|c|c|}
\hline 報告者 & 症例数 & レジメン & 白血球減少 & 血小板減少 & 貧血 & 非血液毒性 \\
\hline Autman & 170 & $\begin{array}{l}\text { MAID } \\
\text { ADM } 60 \mathrm{mg} / \mathrm{m}^{2} \text { IFO } 7.5 \mathrm{~g} / \mathrm{m}^{2} \\
\text { DTIC } 1 \mathrm{~g} / \mathrm{m}^{2}\end{array}$ & $86 \%$ & $26 \%$ & $22 \%$ & $\begin{array}{l}\text { death4\% } \\
\text { nausea/vomiting 19\% } \\
\text { mucositis } 9 \% \\
\text { CNS disorder 6\% }\end{array}$ \\
\hline Frustaci & 53 & $\begin{array}{l}\mathrm{IFO}+\mathrm{EPI} \\
\mathrm{IFO} 9 \mathrm{~g} / \mathrm{m}^{2} \text { EPI } 120 \mathrm{mg} / \mathrm{m}^{2}\end{array}$ & $58 \%$ & $11 \%$ & $20 \%$ & $\begin{array}{l}\text { nausea/vomiting } 3 \% \\
\text { mucositis } 10 \%\end{array}$ \\
\hline
\end{tabular}

表 4 ：IFO+ADM レジメンの有害事象頻度

\begin{tabular}{|c|c|c|c|c|c|c|}
\hline 報告者 & 症例数 & レジメン & 白血球減少 & 血小板減少 & 貧血 & 非血液毒性 \\
\hline Patel & 17 & $\begin{array}{l}\mathrm{IFO}+\mathrm{ADM} \\
\left(10 \mathrm{~g} / \mathrm{m}^{2}\right)\left(90 \mathrm{mg} / \mathrm{m}^{2}\right)\end{array}$ & $87 \%$ & $55 \%$ & & $\begin{array}{l}\text { febrile neutropenia } 47 \% \\
\text { mucositis } 8 \% \\
\text { nausea/vomiting } 9 \%\end{array}$ \\
\hline De Pas & 14 & $\begin{array}{l}\mathrm{IFO}+\mathrm{ADM} \\
\left(12.5 \mathrm{~g} / \mathrm{m}^{2}\right)\left(60 \mathrm{mg} / \mathrm{m}^{2}\right)\end{array}$ & $59 \%$ & $18 \%$ & $25 \%$ & $\begin{array}{l}\text { febrile neutropenia } 16 \% \\
\text { mucositis } 7 \%\end{array}$ \\
\hline 当科 & 9 & $\begin{array}{l}\mathrm{IFO}+\mathrm{ADM} \\
\left(10 \mathrm{~g} / \mathrm{m}^{2}\right)\left(60 \mathrm{mg} / \mathrm{m}^{2}\right)\end{array}$ & $98 \%$ & $0 \%$ & $19 \%$ & $\begin{array}{l}\text { febrile neutropenia } 10 \% \\
\text { infection } 4 \%\end{array}$ \\
\hline
\end{tabular}


infusion of high-dose ifosfamide and doxorubicin as first-line chemotherapy in adult patients with advanced soft tissue sarcomas. Ann. Oncol., 13(1) : 161-166, 2002.

4) Frustaci, S., et al. : Adjuvant chemotherapy for adult soft tissue sarcomas of the extremities and girdles : results of the Italian randomized cooperative trial. Journal of clinical oncology, 19(5) : 1238-1247, 2001.

5) Patel, S. R., et al. : Results of two consecutive trials of dose-intensive chemotherapy with doxorubicin and ifosfamide in patients with sarcomas. Am. J. Clin. Oncol., 21(3) : 317-321, 1998. 